\title{
Efektivitas Pengolahan Air yang Mengandung Amonia Konsentrasi Tinggi Menggunakan Konsorsium Probiotik Komersial dan Bakteri Sedimen Kolam Lele
}

\section{Treatement Effectivity for Water Containing High Concentration Ammonia Using Commercial Probiotic Consortium and Sediment Bacteria from Catfish Pond}

\author{
HANIES AMBARSARI ${ }^{*}$, IMAN SYAH ${ }^{2}$, RUDI NUGROHO ${ }^{1}$, \\ BRIAN SAPUTRA MANURUNG ${ }^{3}$, FUZI SUCIATI ${ }^{1}$ \\ ${ }^{1}$ Pusat Teknologi Lingkungan, Badan Penkajian dan Penerapan Teknologi, Tangerang Selatan, Banten \\ ${ }^{2}$ Program Studi Biologi, Fakultas IImu Hayati, Surya University, Tangerang, Banten \\ ${ }^{3}$ Surya University, Tangerang, Banten
}

\begin{abstract}
Nitrification is one of the most widely used methods to reduce ammonia concentration in wastewater. The purpose of this study was to determine the effectiveness of high-concentrated ammonia nitrification by the consortium between commercial probiotics and bacteria from the sediment of the catfish pond. The study was conducted on batch system bioreactors with a working volume of 1 liter containing $100 \mathrm{mg} / \mathrm{L}$ ammonia solution and 50 grams sediment of catfish pond. This study used a treatment variation of the concentration of commercial probiotics and the bacterial isolate from the catfish pond sediment using glucose as the carbon source. The variations of commercial probiotics added to the bioreactor were 5 $\mathrm{ml} / \mathrm{L}, 10 \mathrm{ml} / \mathrm{L}$ and $15 \mathrm{ml} / \mathrm{L}$. The variations of glucose concentration were $0 \mathrm{~g} / \mathrm{L}$ and $3,9 \mathrm{~g} / \mathrm{L}$. Analysis of ammonia concentration was carried out by spectrophotometry using the phenate method. The highest removal efficiency of ammonia was $92.35 \%$ in the bioreactor with a mixture of $15 \mathrm{ml} / \mathrm{L}$ commercial probiotics and $3.9 \mathrm{~g} / \mathrm{L}$ glucose with the fastest ammonia rate was on the third day of the experimental period. The addition of glucose in the bioreactors could increase ammonia removal by $57.39 \%$. The result of statistical analysis indicated that variations in the concentration of commercial probiotic indicated no statistically significant difference in ammonia removal $(P>0.05)$, while variations in glucose concentration showed a statistically significant difference in ammonia removal $(P<0.05)$. Three isolates were successfully isolated on specific media for nitrifying bacteria. The result of bacterial identification showed that three isolated bacteria were Bacillus sp., Aeromonas salmonicida, and Burkholderia cepacia.
\end{abstract}

Keywords: ammonia, nitrification, sediment of catfish pond, commercial probiotic

\begin{abstract}
ABSTRAK
Nitrifikasi merupakan salah satu metode yang paling banyak digunakan untuk mengurangi konsentrasi amonia pada limbah cair. Penelitian ini bertujuan untuk mengetahui efektivitas penambahan sedimen kolam lele dan probiotik komersial dalam nitrifikasi amonia konsentrasi tinggi. Penelitian menggunakan bioreaktor sistem batch dengan volume kerja 1 liter yang berisi larutan amonia $100 \mathrm{mg} / \mathrm{L}$ dan $50 \mathrm{gram}$ sedimen kolam lele. Perlakuan pada penelitian ini terdiri dari pemberian variasi konsentrasi probiotik komersial dan sedimen kolam lele dengan sumber karbon glukosa. Variasi probiotik komersial yang ditambahkan pada bioreaktor adalah $5 \mathrm{ml} / \mathrm{L}, 10 \mathrm{ml} / \mathrm{L}$ dan $15 \mathrm{ml} / \mathrm{L}$ sedangkan variasi konsentrasi glukosa adalah $0 \mathrm{~g} / \mathrm{L}$ dan $3,9 \mathrm{~g} / \mathrm{L}$. Analisis konsentrasi amonia dilakukan secara spektrofotometri menggunakan Metode Fenat. Hasil penurunan rata-rata amonia tertinggi adalah sebesar $92,35 \%$ pada bioreaktor dengan campuran probiotik komersial $15 \mathrm{ml} / \mathrm{L}$ dan glukosa $3,9 \mathrm{~g} / \mathrm{L}$ dengan laju penurunan ammonia tercepat pada hari ke-3 periode eksperimen. Penambahan glukosa pada bioreaktor mampu meningkatkan penurunan amonia sebesar $57,39 \%$. Analisis statistik menunjukkan bahwa variasi konsentrasi probiotik komersial tidak menunjukkan perbedaan signifikan pada penurunan amonia $(p>0,05)$ sedangkan variasi konsentrasi glukosa menunjukkan perbedaan yang signifikan terhadap penurunan amonia $(p<0,05)$. Tiga isolat berhasil diisolasi menggunakan media spesifik bakteri nitrifikasi. Hasil identifikasi dari tiga bakteri menunjukkan bahwa isolat tersebut adalah Bacillus sp., Aeromonas salmonicida dan Burkholderia cepacia.
\end{abstract}

Kata kunci: amonia, nitrifikasi, sedimen kolam lele, probiotik komersial 


\section{PENDAHULUAN}

Air merupakan salah satu sumber daya alam yang sangat penting yang harus dijaga untuk kelangsungan hidup. Hampir semua aktivitas manusia memerlukan air, seperti pertanian, perkebunan dan aktivitas rumah tangga. Seiring dengan perkembangan zaman dan pesatnya aktivitas industri, kualitas air mengalami penurunan. Salah satu penyebab penurunan kualitas air adalah limbah cair industri yang biasanya langsung dibuang ke sungai tanpa diolah terlebih dahulu sehingga menyebabkan pencemaran air.

Kandungan zat yang terdapat pada limbah cair dapat menimbulkan berbagai macam masalah. Salah satu masalah yang ditimbulkan oleh limbah cair adalah gangguan pada kesehatan. Menurut data UN World Water Assessment Programme, sekitar 2,3 milyar orang menderita penyakit yang berhubungan dengan air tercemar mikroba patogen, seperti skistosomiasis, disentri, tifoid dan kolera ${ }^{(1)}$. Limbah cair yang mengandung zat kimia, seperti dichlorodiphenyltrichloroethane (DDT), dioksin, polychlorinated biphenyl (PCB) dan logam berat dapat menyebabkan iritasi kulit dan kanker ${ }^{(2)}$.

Selain memiliki dampak kesehatan, pencemaran air juga memiliki dampak pada lingkungan. Salah satu dampak pencemaran air bagi lingkungan adalah eutrofikasi. Eutrofikasi disebabkan karena meningkatnya konsentrasi unsur hara, seperti fosfor dan nitrogen. Hal ini menyebabkan pertumbuhan alga menjadi meningkat sehingga dapat mengurangi oksigen terlarut pada perairan ${ }^{(2)}$. Salah satu senyawa yang menyebabkan eutrofikasi adalah amonia. Selain memiliki dampak pada lingkungan, amonia juga memiliki dampak pada kesehatan ikan dan manusia. Dampak amonia pada manusia adalah iritasi kulit, mata dan sistem pernafasan sedangkan dampak pada ikan adalah pertumbuhan yang lambat, meningkatkan stress dan kerentanan terhadap infeksi bakteri dan penyakit ${ }^{(3)}$. Menurut World Health Organization, ambang batas amonia pada sungai adalah 0,2-0,3 mg/liter ${ }^{(4)}$.

Konsentrasi amonia yang tinggi pada limbah cair perlu diturunkan agar tidak berbahaya pada lingkungan dan kesehatan. Penurunan amonia pada limbah cair dapat dilakukan dengan metode fisikokimia dan biologis ${ }^{(5)}$. Metode fisikokimia adalah metode penyisihan amonia menggunakan prinsip fisika dan kimia, seperti air stripping ${ }^{(6)}$, pengendapan secara kimia ${ }^{(7)}$ dan ion exchange(8). Namun, metode fisikokimia tergolong mahal karena membutuhkan bahan kimia dan dapat mencemari lingkungan dengan senyawa-senyawa yang berbahaya. Alternatif metode lainnya yang lebih ekonomis dan efisien untuk menurunkan konsentrasi amonia pada limbah cair adalah metode biologis ${ }^{(9)}$.

Metode penyisihan amonia secara biologis merupakan salah satu metode yang paling banyak digunakan untuk penyisihan limbah cair yang mengandung amonia. Metode ini memiliki dua tahap proses, yaitu pertama oksidasi amonia menjadi nitrit dan tahap kedua oksidasi nitrit menjadi nitrat oleh bakteri nitrifikasi dalam kondisi aerobik(10). Tahap pertama adalah oksidasi amonia menjadi nitrit oleh bakteri pengoksidasi amonia (AOB; ammonia-oxidizing bacteria), contohnya Nitrosomonas dan Bacillus $^{(11)}$. Tahap kedua adalah oksidasi nitrit menjadi nitrat oleh bakteri pengoksidasi nitrit (NOB; nitrite-oxidizing bacteria), contohnya Nitrobacter, Bacillus dan Nitrospira(12).

Probiotik komersial merupakan salah satu produk yang banyak digunakan untuk mengurangi konsentrasi amonia pada limbah cair. Bacillus merupakan salah satu bakteri yang banyak digunakan pada probiotik komersial. Menurut Wang et al (13), penggunaan probiotik komersial kurang efisien dalam nitrifikasi limbah amonia. Oleh karena itu, diperlukan konsorsium probiotik komersial dengan spesies bakteri lainnya agar penurunan amonia menjadi optimal dan efisien. Salah satu kandidat yang cocok untuk konsorsium dengan bakteri probiotik komersial adalah bakteri sedimen kolam lele ${ }^{(14)}$. Oleh karena itu, penelitian ini bertujuan untuk mengetahui efektivitas penambahan sedimen kolam lele dan probiotik komersial dalam nitrifikasi amonia pada konsentrasi tinggi.

\section{METODE}

\section{$2.1 \quad$ Waktu dan Tempat}

Penelitian ini dimulai dari Januari 2018 sampai Juli 2018, bertempat di Laboratorium Mikrobiologi, Pusat Teknologi Lingkungan (PTL), Badan Pengkaji dan Penerapan Teknologi (BPPT), Serpong.

\subsection{Pengambilan Sampel Sedimen}

Lokasi pengambilan sedimen dilakukan di kolam lele Desa Pengasinan, Gunung Sindur, Bogor pada 21 Maret 2018. Pengambilan sedimen dilakukan pada lima titik kolam dan sedimen tersebut dicampur pada wadah plastik steril agar sedimen menjadi homogen

\subsection{Aktivasi Probiotik}

Proses aktivasi probiotik menggunakan perbandingan 1:1 untuk probiotik komersial (merk Monodon Plus) dan molase (15 mL probiotik: $15 \mathrm{~mL}$ molase; $10 \mathrm{~mL}$ probiotik: 10 $\mathrm{mL}$ molase dan $5 \mathrm{~mL}$ probiotik: $5 \mathrm{~mL}$ molase) 
dalam 1 liter akuades steril selama 2 hari pada suhu $25^{\circ} \mathrm{C}$.

\subsection{Rancangan Bioreaktor}

Bioreaktor yang digunakan adalah dari botol plastik dengan volume kerja 1 liter yang dihubungkan dengan aerator dengan sistem batch. Bioreaktor dibuat tertutup dengan penambahan selang udara dan air stone agar aerasi merata di setiap bagian bioreaktor. Selang udara diberi kran aerator agar laju aerasi menjadi sama untuk semua bioreaktor. Bioreaktor menggunakan aerator berkapasitas 40 liter/menit. Ilustrasi rancangan bioreaktor dapat dilihat pada Gambar $1^{(15)}$.

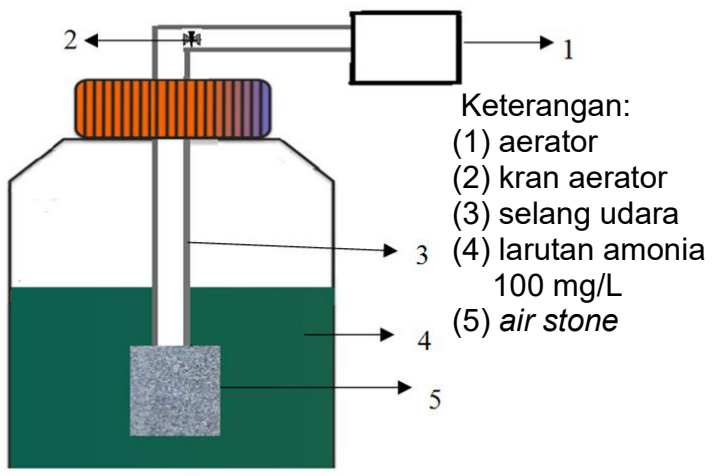

Gambar 1. Ilustrasi rancangan bioreaktor dengan volume kerja 1 liter

\subsection{Prosedur Penelitian}

Larutan amonia dengan konsentrasi 100 $\mathrm{mg} / \mathrm{L}$ dibuat dengan cara melarutkan $733 \mathrm{mg}$ amonium sulfat dalam $1 \mathrm{~L}$ akuades. Amonium sulfat, sedimen kolam lele dan glukosa dimasukkan ke dalam bioreaktor yang mengandung probiotik yang telah diaktivasi. Variasi perlakuan untuk setiap bioreaktor dapat dilihat pada Tabel 1.

Parameter yang diuji pada penelitian ini adalah konsentrasi amonia, nitrit, nitrat, TPC, suhu, $\mathrm{pH}$ dan DO. Uji amonia, nitrit, nitrat, DO, suhu dan $\mathrm{pH}$ dilakukan setiap 3 hari sekali sedangkan TPC dilakukan 7 hari sekali. Variasi perlakuan pada $\mathrm{P} 1, \mathrm{P} 2, \mathrm{P} 3, \mathrm{P} 4, \mathrm{P} 5$ dan $\mathrm{P} 6$ dilakukan pengulangan sebanyak 3 kali (triplo) serta terdapat lima kontrol sehingga total bioreaktor berjumlah 23 unit.

\subsection{Pengujian Amonia}

Pengujian konsentrasi amonia mengikuti acuan dari SNI 06-6989.30-2005. Pengujian konsentrasi amonia dilakukan dengan spektrofotometer secara fenat. Uji amonia secara fenat dapat mengukur amonia dengan kisaran $0,1-0,6 \quad \mathrm{mg} / \mathrm{L} \quad \mathrm{NH}_{3}-\mathrm{N}$ pada panjang gelombang $640 \mathrm{~nm}$.

\subsection{Pengujian Nitrit}

Pengujian konsentrasi nitrit mengikuti acuan dari SNI 06-2484-1991. Pengujian nitrit dengan metode ini dapat mengukur konsentrasi nitrit pada sampel air dengan rentang 0,01-1,0 $\mathrm{mg} / \mathrm{L} \mathrm{NO}_{2}-\mathrm{N}$ pada panjang gelombang $543 \mathrm{~nm}$.

\subsection{Pengujian Nitrat}

Pengujian air yang mengandung nitrat mengikuti acuan dari Ingram \& Anderson ${ }^{(16)}$. Pengujian nitrat dengan metode ini dapat mengukur konsentrasi nitrat pada sampel air hingga $10 \mathrm{mg} / \mathrm{L} \mathrm{NO}_{3}-\mathrm{N}$ pada panjang gelombang $410 \mathrm{~nm}$.

\subsection{Pertumbuhan Bakteria pada Media SpesifikPengujian Nitrat}

Konsorsium bakteria pada bioreaktor kemudian dikultur pada media spesifik untuk membuktikan bahwa bakteri tersebut merupakan golongan bakteri nitrifikasi. Komposisi media spesifik yang digunakan adalah sebagaimana yang tertera pada Tabel $2^{(17)}$.

Tabel 1. Komposisi Media Bioreaktor

\begin{tabular}{ccccccc}
\hline No & Nama Bioreaktor & Probiotik $(\mathbf{m L})$ & Sedimen $(\mathbf{g})$ & Glukosa $(\mathbf{g})$ & Akuades $(\mathbf{m L})$ & Amonia $\mathbf{~ m g / L})$ \\
\hline 1 & K0 & 0 & 0 & 0 & 1000 & 100 \\
\hline 2 & K1A & 10 & 0 & 0 & 990 & 100 \\
\hline 3 & K1B & 10 & 0 & 3,9 & 990 & 100 \\
\hline 4 & K2A & 0 & 50 & 0 & 1000 & 100 \\
\hline 5 & K2B & 0 & 50 & 3,9 & 1000 & 100 \\
\hline 6 & P1 & 15 & 50 & 0 & 985 & 100 \\
\hline 7 & P2 & 15 & 50 & 3,9 & 985 & 100 \\
\hline 8 & P3 & 10 & 50 & 0 & 990 & 100 \\
\hline 9 & P4 & 10 & 50 & 3,9 & 990 & 100 \\
\hline 10 & P5 & 5 & 50 & 0 & 995 & 100 \\
\hline 11 & P6 & 5 & 50 & 3,9 & 995 & 100 \\
\hline Ken
\end{tabular}

Keterangan: K0: kontrol; K1A dan K1B: kontrol positif; K2A dan K2B: kontrol negatif; P1 dan P2: perlakuan konsentrasi probiotik tinggi; P3 dan P4: perlakuan konsentrasi probiotik sedang; P5 dan P6: perlakuan konsentrasi probiotik rendah. 
Tabel 2. Komposisis media spesifik bakteri nitrifikasi

\begin{tabular}{cc}
\hline Komposisi & Massa (per 1 liter media) \\
\hline $\mathrm{KH}_{2} \mathrm{PO}_{4}$ & $13,5 \mathrm{~g}$ \\
\hline $\mathrm{K}_{2} \mathrm{HPO}_{4}$ & $0,7 \mathrm{~g}$ \\
\hline $\mathrm{MgCl}_{2} \cdot 6 \mathrm{H}_{2} \mathrm{O}$ & $0,1 \mathrm{~g}$ \\
\hline $\mathrm{CaCl}_{2} \cdot 2 \mathrm{H}_{2} \mathrm{O}$ & $0,18 \mathrm{~g}$ \\
\hline $\mathrm{NH}_{4} \mathrm{Cl}$ & $0,1 \mathrm{~g}$ \\
\hline $\mathrm{EDTA}$ & $0,2 \mathrm{~g}$ \\
\hline $\mathrm{Na}_{2} \mathrm{CO}_{3}$ & $0,5 \mathrm{~g}$ \\
\hline $\mathrm{FeCl}_{3} \cdot 6 \mathrm{H}_{2} \mathrm{O}$ & $0,18 \mathrm{~g}$ \\
\hline $\mathrm{Glukosa}$ & $0,5 \mathrm{~g}$ \\
\hline
\end{tabular}

\subsection{Pertumbuhan Bakteria pada Media SpesifikPengujian Nitrat}

\subsubsection{Pengamatan Morfologi Koloni dan Pewarnaan Gram}

Pengamatan morfologi koloni bakteri meliputi bentuk dan warna koloni, bentuk tepian koloni, diameter koloni, morfologi permukaan koloni dan bentuk mikroskopis bakteri. Selain itu, dilakukan pewarnaan gram untuk mengetahui jenis bakteri gram positif atau gram negatif.

\subsubsection{Uji Biokimia VITEK 2}

Isolat bakteri yang dapat tumbuh pada media spesifik nitrifikasi kemudian diidentifikasi untuk diketahui spesiesnya. Dalam penelitian ini, identifikasi spesies bakteri nitrifikasi dilakukan dengan alat uji biokimia VITEK 2 di Laboratorium Mikrobiologi Rumah Sakit Siloam, Tangerang, Banten.

\section{HASIL DAN PEMBAHASAN}

\subsection{Parameter Kualitas air}

Parameter kualitas air yang diukur selama penelitian yaitu: suhu, derajat keasaman $(\mathrm{pH})$, total plate count (TPC), oksigen terlarut (DO), konsentrasi amonia $\left(\mathrm{NH}_{4}{ }^{+}\right)$, nitrit $\left(\mathrm{NO}_{2}^{-}\right)$dan nitrat $\left(\mathrm{NO}_{3}{ }^{-}\right)$.

\subsection{Konsentrasi Amonia}

Pengujian konsentrasi amonia pada sampel dilakukan dengan spektrofotometer dan menggunakan metode fenat. Hasil penurunan konsentrasi amonia dan efisiensi penurunan amonia dapat dilihat secara berurutan pada Gambar 2 dan Gambar 3.

Pada penelitian ini, semua bioreaktor mengandung amonia $100 \mathrm{mg} / \mathrm{L}$ dan sedimen kolam lele $50 \mathrm{~g} / \mathrm{L}$. Berdasarkan Gambar 3, efisiensi penurunan konsentrasi amonia pada K1A dan K1B (kontrol positif) secara berurutan adalah $41 \%$ dan $57 \%$. Bioreaktor K1A merupakan bioreaktor yang mengandung probiotik komersial $10 \mathrm{ml} / \mathrm{L}$ dan bioreaktor K1B mengandung probiotik komersial $10 \mathrm{ml} / \mathrm{L}$ dan 3,9 gram glukosa. Berdasarkan perbandingan hasil penurunan konsentrasi amonia pada hari ke-33 (Gambar 2), pengolahan amonia dengan penambahan glukosa dapat meningkatkan efisiensi nitrifikasi pada kontrol positif sebesar $27,11 \%$.

Efisiensi penurunan konsentrasi amonia pada K2A dan K2B (kontrol negatif) secara berurutan adalah $72 \%$ dan $86 \%$. Bioreaktor K2A merupakan bioreaktor yang mengandung sedimen kolam lele $50 \mathrm{~g} / \mathrm{L}$ dan bioreaktor $\mathrm{K} 2 \mathrm{~B}$ mengandung sedimen kolam lele $50 \mathrm{~g} / \mathrm{L}$ dan 3,9 gram glukosa. Berdasarkan perbandingan hasil penurunan konsentrasi amonia pada hari ke-33 (Gambar 3), pengolahan amonia dengan penambahan glukosa dapat meningkatkan efisiensi nitrifikasi pada kontrol negatif sebesar $50 \%$.

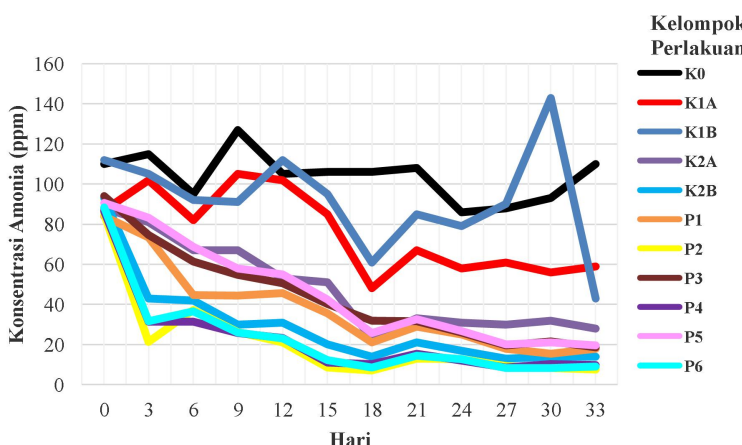

Gambar 2. Grafik penurunan konsentrasi amonia pada bioreaktor

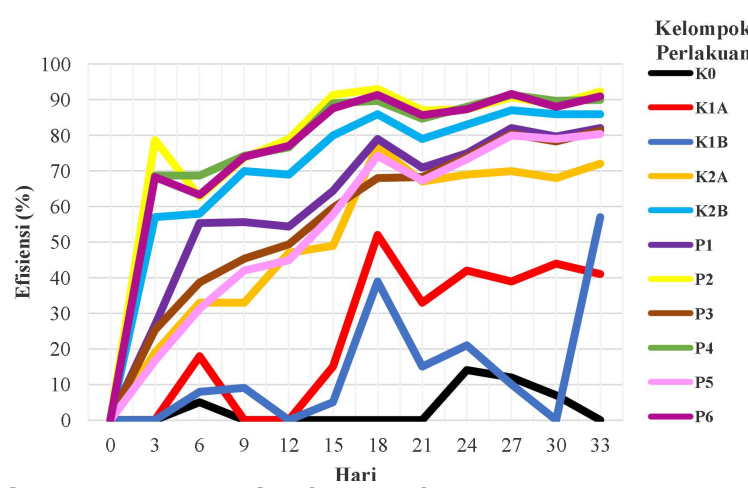

Gambar 3. Grafik ${ }^{\text {Hari }}$ efisiensi penurunan konsentrasi amonia pada bioreaktor

Konsorsium probiotik komersial dan bakteri sedimen kolam lele terdapat pada bioreaktor P1, P2, P3, P4, P5 dan P6. Efisiensi penurunan konsentrasi amonia pada $\mathrm{P} 1$ dan P2 secara berurutan adalah $82 \%$ dan $92,33 \%$. Bioreaktor P1 adalah bioreaktor yang mengandung probiotik komersial $15 \mathrm{ml} / \mathrm{L}$ dan bioreaktor P2 mengandung probiotik komersial $15 \mathrm{ml} / \mathrm{L}$ dan 3,9 g/L glukosa. Berdasarkan Gambar 3, perbandingan hasil penurunan konsentrasi amonia pada P1 dan P2 saat hari ke-33 
menunjukkan bahwa penambahan glukosa dapat meningkatkan penurunan amonia sebesar $57,39 \%$.

Efisiensi penurunan konsentrasi amonia pada P3 dan P4 secara berurutan adalah $81,33 \%$ dan $90 \%$. Bioreaktor P3 adalah bioreaktor yang mengandung probiotik komersial $10 \mathrm{ml} / \mathrm{L}$ dan bioreaktor P4 mengandung probiotik komersial $10 \mathrm{ml} / \mathrm{L}$ dan 3,9 g/L glukosa. Jika hasil penurunan konsentrasi amonia dibandingkan antara P3 dan P4 pada saat hari ke-33, maka dapat diketahui bahwa efek penambahan glukosa pada bioreaktor P4 mampu meningkatkan penurunan amonia sebesar 48,20\%.

Efisiensi penurunan konsentrasi amonia pada P5 dan P6 secara berurutan adalah $80,33 \%$ dan 91\%. Bioreaktor P5 adalah bioreaktor yang mengandung probiotik komersial $5 \mathrm{ml} / \mathrm{L}$ dan bioreaktor P6 mengandung probiotik komersial $5 \mathrm{ml} / \mathrm{L}$ dan 3,9 g/L glukosa. Berdasarkan Gambar 3, perbandingan hasil penurunan konsentrasi amonia pada P5 dan P6 saat hari ke-33 menunjukkan bahwa penambahan glukosa dapat meningkatkan penurunan amonia sebesar $54,24 \%$.

Berdasarkan penjelasan di atas, sebagian besar bioreaktor yang mengandung konsorsium probiotik komersial dan bakteri sedimen kolam lele memiliki nilai efisiensi penurunan amonia yang lebih baik dibandingkan hasil efisiensi penurunan amonia pada bioreaktor kontrol posif dan kontrol negatif. Hal ini menunjukkan bahwa konsorsium probiotik komersial dan bakteri sedimen kolam lele lebih baik dalam proses pengolahan amonia dibandingkan hanya menggunakan probiobik komersial atau hanya menggunakan bakteri sedimen kolam lele. Berdasarkan data di atas, nilai efisiensi penurunan amonia tertinggi adalah pada bioreaktor P2, yaitu sebesar 92,33\% dan penambahan glukosa mampu meningkatkan penurunan amonia maksimal sebesar $57,39 \%$.

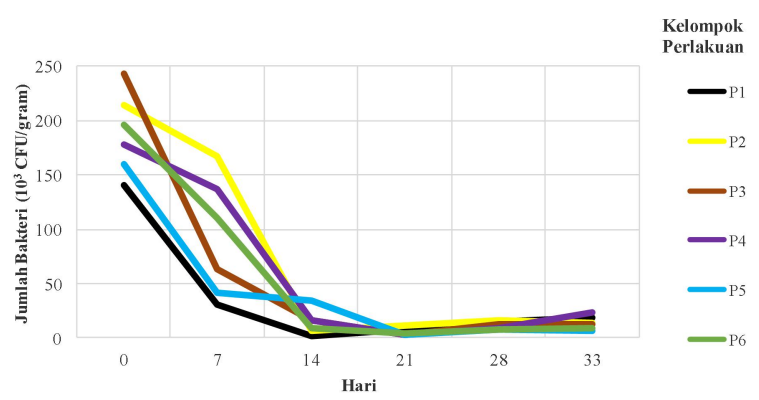

Gambar 4. Grafik hasil total plate count (TPC)

Pengujian parameter dilakukan selama 33 hari karena hasil penurunan konsentrasi amonia pada hari ke-30 dan hari ke-33 cenderung konstan. Tetapi dari grafik Gambar 2 dan
Gambar 3 dapat terlihat bahwa laju penurunan amonia yang paling cepat adalah pada periode 0-3 hari untuk semua perlakuan selain kontrol. Penurunan konsentrasi amonia yang konstan setelah hari ke-30 mungkin disebabkan karena jumlah populasi bakteri nitrifikasi pada bioreaktor yang semakin berkurang. Hal ini sesuai dengan data TPC (Gambar 4) yang menunjukkan bahwa populasi jumlah bakteri pada bioreaktor saat hari ke-30 dan hari ke-33 sudah berkurang. Penurunan populasi bakteri pada perlakuan $\mathrm{P} 2$ terlihat lebih lambat daripada perlakuan-perlakuan lainnya dan hal ini sesuai dengan nilai efisiensi penurunan amonia tertinggi pada perlakuan P2 yang ditunjukkan selama penelitian.

\subsection{Konsentrasi Nitrit dan Nitrat}

Nitrifikasi merupakan proses pengubahan amonia menjadi nitrit dan kemudian diubah menjadi nitrat. Oleh karena itu, dilakukan uji nitrit dan nitrat pada bioreaktor. Berdasarkan Gambar 5, sebagian besar konsentrasi nitrit pada bioreaktor tergolong sedikit. Hal ini disebabkan karena nitrit adalah senyawa intermediet yang terbentuk pada proses nitrifikasi sehingga nitrit yang terbentuk langsung diubah menjadi nitrat yang menyebabkan konsentrasi nitrit sedikit ${ }^{(18)}$. Pembentukan konsentrasi nitrit mulai meningkat pada hari ke-6, hari ke-9 dan hari ke-12 kemudian konsentrasi nitrit mulai menurun hingga hari ke-33. Pembentukan nitrit tertinggi terjadi pada hari ke-9 pada bioreaktor P2, yaitu sebesar 21,92 ppm.

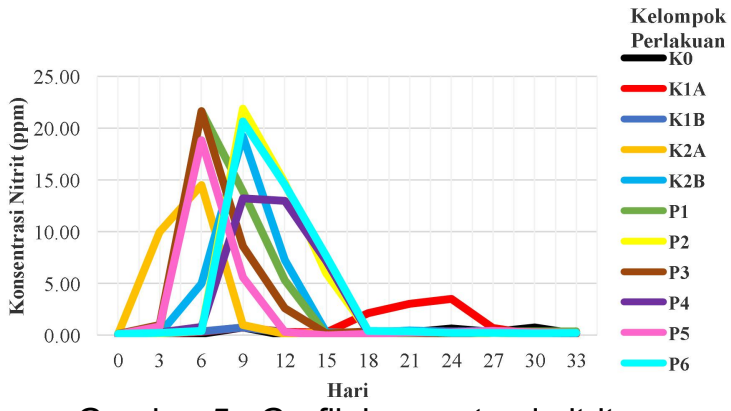

Gambar 5. Grafik konsentrasi nitrit

Berdasarkan Gambar 6, sebagian besar konsentrasi nitrat pada bioreaktor tergolong tinggi. Hal ini disebabkan karena akumulasi dari hasil proses nitrifikasi amonia. Hal ini sesuai dengan penelitian Komarawidjaja(19), yang menyatakan bahwa konsentrasi nitrat seharusnya terus meningkat pada proses nitrifikasi. Pembentukan nitrat mulai terbentuk pada hari ke-9 dan cenderung terus meningkat hingga hari ke-33. 


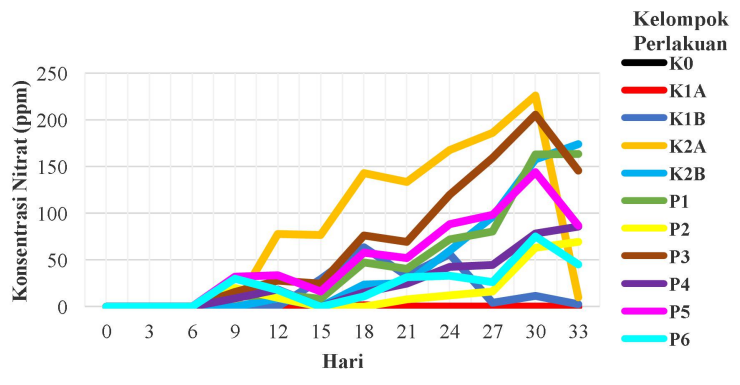

Gambar 6. Grafik konsentrasi nitrat

\subsection{Parameter Kualitas air}

Suhu merupakan salah satu faktor yang sangat mempengaruhi proses nitrifikasi. Suhu pada bioreaktor tergolong optimal untuk pertumbuhan bakteri nitrifikasi, yaitu berkisar antara $26^{\circ} \mathrm{C}-28^{\circ} \mathrm{C}$. Hal ini sesuai dengan penelitian $\mathrm{Li}$ et al. ${ }^{(20)}$, yang menyatakan bahwa nitrifikasi mencapai laju maksimum pada suhu sekitar $30^{\circ} \mathrm{C}$ dan laju nitrifikasi menjadi menurun jika suhu kurang dari $15^{\circ} \mathrm{C}$. Lebih lanjut disebutkan dalam studi yang lain bahwa kondisi iklim suatu daerah ternyata ikut berpengaruh terhadap laju proses nitrifikasi. Pada musim dingin dan musim semi laju nitrifikasi dapat lebih tinggi daripada pada musim panas ${ }^{(21)}$.

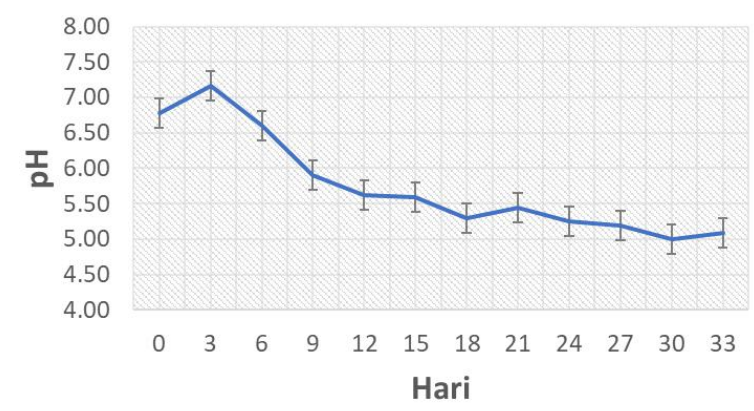

Gambar 7. Grafik perubahan $\mathrm{pH}$ pada bioreaktor

Salah satu faktor lainnya yang sangat mempengaruhi proses nitrifikasi adalah derajat keasaman $(\mathrm{pH})$ karena faktor $\mathrm{pH}$ ini yang akan menentukan apakah nitrit atau nitrat yang akan dihasilkan di akhir proses nitrifikasi(22). Sebaliknya, proses nitrifikasi menghasilkan asam yang dapat menyebabkan penurunan $\mathrm{pH}^{(10)}$. Hal ini sesuai dengan data pada Gambar
7 yang menunjukkan bahwa $\mathrm{pH}$ pada sebagian besar bioreaktor cenderung mengalami penurunan. Hasil studi terhadap pengaruh dari variasi $\mathrm{pH}$ terhadap proses nitrifikasi menurut penelitian sebelumnya menunjukkan bahwa oksidasi ammonia terhambat sepenuhnya pada $\mathrm{pH} 5$, sedangkan oksidasi nitrit akan sangat terhambat pada $\mathrm{pH} 8,5$. Nilai $\mathrm{pH}$ optimal untuk kinerja bakteria pengoksidasi ammonia $(A O B$, ammonium oxidizing bacteria) maupun bakteria pengoksidasi nitrit (NOB, nitrite oxidizing bacteria) adalah pada kisaran $\mathrm{pH} 7-7,5^{(23)}$.

Selain suhu dan $\mathrm{pH}$, faktor lainnya yang sangat mempengaruhi proses nitrifikasi adalah dissolved oxygen (DO). Perubahan nilai DO pada bioreaktor selama penelitian kami ini berkisar antara 5,5-8,0 mg/L. Menurut Ward et al.(10), nilai DO yang optimal untuk proses nitrifikasi adalah sekitar $2 \mathrm{mg} / \mathrm{L}$. Dari penelitian sebelumnya juga diperoleh data bahwa nilai DO yang rendah $(0,4 \quad-0,8 \mathrm{mg} / \mathrm{L})$ akan menyebabkan proses nitrifikasi berjalan lebih efisien $44 \%$ dibandingkan dengan nilai DO yang tinggi (lebih dari $3 \mathrm{mg} / \mathrm{L}$ ) dengan efisiensi hanya $7,7 \%(24)$.

\subsection{Parameter Kualitas air}

Setelah dikultur pada media spesifik nitrifikasi, terdapat tiga isolat bakteri yang berhasil diisolasi dari bioreaktor nitrifikasi yaitu isolat $\mathrm{K}-1$, isolat $\mathrm{K}-2$, dan isolat $\mathrm{K}-3$ (Gambar 8). Hasil identifikasi menggunakan uji VITEK 2 menunjukkan bahwa isolat $\mathrm{K}-2$ adalah Aeromonas salmonicida dan isolat K-3 adalah Burkholderia cepacia. Isolat K-1 diidentifikasi secara manual berdasarkan hasil pewarnaan gram dan morfologi bakteri yang menunjukkan bahwa isolat K-1 diduga adalah Bacillus $\mathrm{sp}$. Morfologi koloni, sifat gram dan bentuk sel dari ketiga isolat ini dapat dilihat pada Tabel 3.

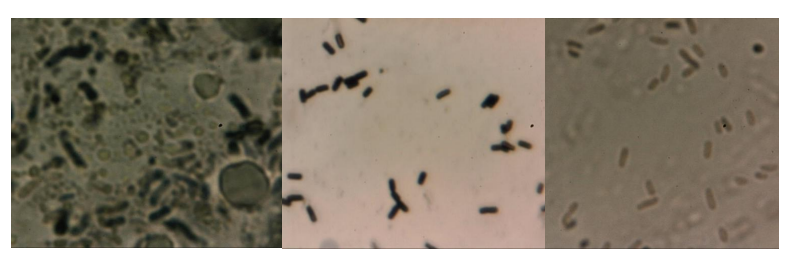

Gambar 8. Isolat K-1 (kiri), isolat K-2 (kanan) dan isolat $\mathrm{K}-3$ (bawah)

Tabel 3. Data morfologi, sifat gram dan bentuk sel isolat bakteri

\begin{tabular}{|c|c|c|c|c|c|c|}
\hline \multirow[t]{2}{*}{ Isolat } & \multicolumn{4}{|c|}{ Morfologi Koloni } & \multirow{2}{*}{$\begin{array}{c}\text { Sifat } \\
\text { Gram }\end{array}$} & \multirow{2}{*}{$\begin{array}{c}\text { Bentuk } \\
\text { Sel }\end{array}$} \\
\hline & Bentuk & Tepi & Elevasi & Warna & & \\
\hline $\mathrm{K}-1$ & Bulat & Halus & Datar & Putih & Positif & Basil \\
\hline $\mathrm{K}-2$ & Bulat & Halus & Datar & Merah & Negatif & Basil \\
\hline K-3 & Kecil & Halus & Datar & Putih & Negatif & Basil \\
\hline
\end{tabular}




\section{KESIMPULAN}

Berdasarkan hasil dan pembahasan tersebut, konsorsium probiotik komersial dan bakteri sedimen kolam lele mampu menurunkan amonia sampai sebesar $92,35 \%$ dangan konsentrasi awal 100 ppm. Selain itu, pemberian glukosa dapat meningkatkan proses nitrifikasi sampai sebesar $57,39 \%$. Hasil variasi konsentrasi probiotik komersial pada penelitian ini menunjukkan tidak adanya perbedaan yang signifikan terhadap penurunan konsentrasi amonia $(p>0,05)$ sedangkan variasi konsentrasi glukosa menunjukkan perbedaan yang signifikan terhadap penurunan amonia $(p<0,05)$. Nilai efisiensi penurunan amonia tertinggi sebesar $92,35 \%$ terjadi pada perlakukan P2 dengan komposisi media dalam bioreaktornya ditambah dengan $15 \mathrm{~mL}$ Probiotik komersial merk Monodon Plus.

\section{PERSANTUNAN}

Kontributor utama publikasi adalah Hanies Ambarsari, sedangkan penulis lainnya adalah kontributor anggota. Kegiatan riset ini mendapatkan bantuan dana Insentif SINAS 2019 dari Kementerian RistekDikti atas nama Dr. Hanies Ambarsari, BSc., M.AppISc dan dilaksanakan dengan menggunakan fasilitas laboratorium lingkungan Pusat Teknologi Lingkungan (PTL) - BPPT. Terima kasih kepada semua analis litkayasa dan teknisi PTL-BPPT yang tergabung di dalam Tim InSinas 2019.

\section{DAFTAR PUSTAKA}

1. United Nations World Water Assessment Programme. (2003). The United Nations World Water Development Report 2003: Water for People, Water for Life. Paris, UNESCO.

2. Calhoun, Y. \& Seideman, D. (2005). Water pollution. Philadelphia: Chelsea House Publishers.

3. Hargreaves, J. A., \& Tucker, C. S. (2004). Managing ammonia in fish ponds (Vol. 4603). Stoneville: Southern Regional Aquaculture Center.

4. World Health Organization. (2008). Guidelines for drinking-water quality. Geneva, WHO

5. Ahn, Y. H. (2006). Sustainable nitrogen elimination biotechnologies: a review. Process Biochemistry, 41(8), 1709-1721.

6. Guštin, S., \& Marinšek-Logar, R. (2011). Effect of $\mathrm{pH}$, temperature and air flow rate on the continuous ammonia stripping of the anaerobic digestion effluent. Process Safety and Environmental Protection, 89(1), 61-66.
7. Quan, X., Ye, C., Xiong, Y., Xiang, J., \& Wang F. (2010). Simultaneous removal of ammonia, $P$ and COD from anaerobically digested piggery wastewater using an integrated process of chemical precipitation and air stripping. Journal of Hazardous Materials, 178(1), 326-332.

8. Jorgensen, T. C., \& Weatherley, L. R. (2003). Ammonia removal from wastewater by ion exchange in the presence of organic contaminants. Water Research, 37(8), 17231728.

9. Barber, W. P., \& Stuckey, D. C. (2000). Nitrogen removal in a modified anaerobic baffled reactor (ABR) 1, denitrification. Water Research, 34(9), 2413-2422.

10.Ward, B., Arp, D. \& Klotz, M. (2011). Nitrification. Washington, DC: ASM Press

11. Kim, J. K., Park, K. J., Cho, K. S., Nam, S. W., Park, T. J., \& Bajpai, R. (2005). Aerobic nitrification-denitrification by heterotrophic Bacillus strains. Bioresource Technology, 96(17), 1897-1906.

12. Loehr, R. (2012). Agricultural waste management: problems, processes, and approaches. Elsevier.

13.Wang, S., Liu, J., Li, C., \& Chung, B. M. (2018). Efficiency of Nannochloropsis oculata and Bacillus polymyxa symbiotic composite at ammonium and phosphate removal from synthetic wastewater. Environmental technology, 1-26.

14. Gross, A., Boyd, C. E., \& Wood, C. W. (2000). Nitrogen transformations and balance in channel catfish ponds. Aquacultural Engineering, 24(1), 1-14.

15. Ali, T. U., Ahmed, Z., \& Kim, D. J. (2014). Estimation of $\mathrm{N} 2 \mathrm{O}$ emission during wastewater nitrification with activated sludge: effect of ammonium and nitrite concentration by regression analysis. Journal of Industrial and Engineering Chemistry, 20(4), 2574-2579.

16. Ingram, J. \& Anderson, J. (1993). Tropical soil biology and fertility: a handbook of methods. Wallingford: $C A B$ International.

17. Yosmaniar, Y., Novita, H., \& Setiadi, E. (2018) Isolasi dan karakterisasi bakteri nitrifikasi dan denitrifikasi sebagai kandidat probiotik. Jurnal Riset Akuakultur, 12(4), 369-378

18. Shen, Q. R., Ran, W., \& Cao, Z. H. (2003). Mechanisms of nitrite accumulation occurring in soil nitrification. Chemosphere, 50(6), 747753. 
19.Komarawidjaja, W. (2011). Pengaruh perbedaan dosis oksigen terlarut (DO) pada degradasi amonium

20. kolam kajian budidaya udang. Jurnal Hidrosfir Indonesia, 1(1).

21.Li, C., Yang, J., Wang, X., Wang, E., Li, B., He, R., et al. (2015). Removal of nitrogen by heterotrophic nitrification-aerobic denitrification of a phosphate accumulating bacterium Pseudomonas stutzeri YG-24. Bioresour. Technol. 182, 18-25. doi: 10.1016/j.biortech.2015.01.100.

22.Beer, S.E., Connelly, T.L., Sipler, R.E., Yager, P.L., and Bronk, D.A. (2014). Effect of temperature on rates of ammonium uptake and nitrification in the western coastal Arctic during winter, spring, and summer. Global Biogeochem. Cycles. 28,14551466.doi:10.1002/2013GB004765.

23. Fumasoli, A., Morgenroth, E., and Udert, K.M. (2015). Modelling the low $\mathrm{pH}$ limit of Nitrosomonas eutropha in high-strength nitrogen wastewaters. Water Research. 83, 161-170.doi:10.1016/j.watres.2015.06.013.

24. Huyen Le, T.T., Fettig, J., Meon, G. (2019). Kinetics and simulation of nitrification at various $\mathrm{pH}$ values of a polluted river in the tropics. Ecohydrology \& Hydrobiology. 19, 5465.doi:10.1016 /j.ecohyd.2018.06.006. 